\title{
PENYELESAIAN KASUS KEKERASAN DALAM RUMAH TANGGA (KDRT) DI LUAR PENGADILAN
}

\author{
Irwan Niza', Abdul Sakban² \\ ${ }^{1}$ Pendidikan Pancasila dan Kewarganegaraan, Universitas Muhammadiyah Mataram, irwan.niza23@gmail.com \\ ${ }^{2}$ Program Studi Pendidikan Pancasila dan Kewarganegaraan FKIP Universitas Muhammadiyah Mataram, sakban.elfath@yahoo.co.id
}

\begin{abstract}
INFO ARTIKEL
Riwayat Artikel:

Diterima: 10-Januari-

2017

Disetujui: 12 Maret-2017

\section{Kata Kunci:}

Penyelesaian

KDRT

Luar Pengadilan

Abstrak: Kekerasan yang terjadi dalam rumah tangga lebih banyak dialami perempuan yang berkedudukan sebagai seorang istri, sedangkan pelakunya didominasi oleh laki-laki yang berkedudukan sebagai seorang suami. Hal ini desebabkan oleh faktor internal antara lain yaitu karakter pelaku kekerasan yang cenderung emosi, ketergantungan ekonomi, pihak ketiga dalam rumah tangga. Faktor eksternal antara lain perbedaan budaya/kebiasaan, perbedaan agama atau keyakinan pasangan suami-istri dan keduanya tidak saling memahami satu sama lain. Dalam kasus ini proses penyelesaianya yaitu melalui jalur mediasi atau diselesaikan di luar pengadilan. Metode yang digunakan dalam penelitin ini adalah metode kualitatif dengan pendekatan diskriptif. Subjek penelitian ini adalah Tokoh adat, tokoh agama, kepala desa kepala dusun dan masyarakat setempat. Metode pengumpulan data menggunakan observasi, wawancara, dan dokumentasi. Sedangkan jenis data yang digunakan adalah data kualitatif dengan metode analisis interaktif. Hasil penelitian ini menyebutkan bahwa 1) Faktor-faktor pendorong terjadinya kasus Kekerasan Dalam Rumah Tangga adanya orang ketiga atau pelaku melakukan perselingkuhan, adanya pernikahan di bawah umur (pernikahan dini), ikut campurnya mertua dan pihak lain dan kesenjangan ekonomi. 2) Proses penyelesaian kasus Kekerasan Dalam Rumah Tangga di luar Pengdilan yaitu tahap sebelum penyelesaian sengketa (pra mediasi), tahap penyelesaian sengketa (tahap mediasi), tahap akhir penyelesaian sengketa (tahap akhir mediasi).
\end{abstract}

\section{A. LATAR BELAKANG}

Dewasa ini kekerasan terhadap perempuan terus mengalami peningkatan walaupun telah dilakukan beberapa upaya dari seluruh lapisan masyarakat untuk menanggulanginya. Akan tetapi tampaknya pelaku kekerasan pun tidak merasa takut akan penegakan hukum yang telah dilakukan. Hal ini dikarenakan adanya pandangan masyarakat bahwa perempuan adalah makhluk yang lebih rendah dibandingkan oleh

\begin{abstract}
Violence that occurs in the household is more experienced by women who are domiciled as wives, while the perpetrators are dominated by men who are domiciled as husbands. This is caused by internal factors, among others, namely the character of the perpetrators of violence who tend to be emotional, economic dependency, third parties in the household. External factors include differences in culture / habits, differences in religion or beliefs of married couples and both do not understand each other. In this case the settlement process is through mediation or resolved outside the court. The method used in this research is a qualitative method with a descriptive approach. The subjects of this study were adat leaders, religious leaders, village heads, hamlet heads and local communities. Methods of collecting data using observation, interviews, and documentation. While the type of data used is qualitative data with interactive analysis methods. The results of this study state that 1) Factors driving the occurrence of cases of Domestic Violence are third people or perpetrators of infidelity, the existence of underage marriages (early marriage), interference from in-laws and other parties and economic disparities. 2) The process of resolving cases of domestic violence outside Pengdilan namely the stage before dispute resolution (pre mediation), the stage of dispute resolution (mediation stage), the final stage of dispute resolution (the final stage of mediation).
\end{abstract}

laki-laki yang mempunyai kedudukan yang lebih tinggi. Adanya strukturalisasi dalam masyarakat itu menimbulkan adanya ketimpangan atau ketidakadilan jender.

Ketimpangan jender adalah perbedaan peran dan hak antara perempuan dan laki-laki di masyarakat yang menempatkan perempuan dalam status lebih rendah dari laki-laki. "Hak istimewa" yang dimiliki laki-laki ini seolah-olah menjadikan perempuan sebagai barang milik laki-laki yang berhak untuk diperlakukan semena- 
mena, termasuk dengan cara kekerasan. Pandangan masyarakat ini telah menghapus hak-hak dari perempuan baik dalam rumah tangga maupun lingkungan yang sejatinya ada. Kekerasan yang dialami oleh perempuan tidak hanya dijumpai di dalam lingkungan masyarakat tetapi juga dapat ditemukan dalam lingkungan rumah tangga.

Dalam Undang-Undang No. 23 tahun 2004 tentang Penghapusan Kekerasan dalam Rumah Tangga menyebutkan bahwa "Kekerasan dalam Rumah Tangga adalah setiap perbuatan terhadap seseorang terutama perempuan, yang berakibat timbulnya kesengsaraan atau penderitaan secara fisik, seksual, psikologis, dan/atau penelantaran rumah tangga termasuk ancaman untuk melakukan perbuatan, pemaksaan, atau perampasan kemerdekaan secara melawan hukum dalam lingkup rumah tangga (Pasal 1 ayat 1 )".

Berdasarkan pasal 2 ayat 1 Undang-Undang Penghapusan Kekerasan Dalam Rumah Tangga, para pihak yang merupakan lingkup keluarga adalah 1) Suami, istri dan anak. 2) Orang-orang yang mempunyai hubungan kekeluargaan dengan orang sebagaimana yang dimaksud pada huruf a karena hubungan darah, perkawinan, persusuan, pengasuhan, dan perwalian yang menetap dalam rumah tangga dan/ atau 3) Orang yang bekerja membantu[1].

Kekerasan yang terjadi dalam rumah tangga lebih banyak dialami perempuan yang di sini berkedudukan sebagai seorang istri atau anak yang menjadi korban, sedangkan pelakunya didominasi oleh laki-laki yang berkedudukan sebagai seorang suami atau anak. Kekerasan dalam rumah tangga dapat disebabkan oleh berbagai faktor, baik faktor internal maupun eksternal dalam lingkup rumah tangga.

Faktor internal yang dapat memicu terjadinya kekerasan dalam rumah tangga antara lain, karakter pelaku kekerasan yang cenderung emosi, ketergantungan ekonomi, pihak ketiga dalam rumah tangga, keadaan ekonomi, dan komunikasi yang berjalan dengan tidak baik. Sementara faktor eksternal yang dapat memicu terjadinya kekerasan dalam rumah tangga antara lain, perbedaan budaya/kebiasaan seperti bila suami berasal dari suku tertentu yang terkenal keras, sedangkan si istri berasal dari suku tertentu yang bersifat lemah lembut, mereka walaupun sudah menjadi suami-istri yang harusnya saling memahami dan saling menerima satu sama lain, justru itu tidak terjadi, yang akhirnya terjadilah egoisme masing-masing dan memaksakan kehendaknya sehingga munculah tindak kekerasan di dalam keluarga tersebut yang memandang perempuan sebelah mata dan faktor seperti kesalahan penafsiran ajaran agama didalam masyarakat, seperti perbedaan agama/keyakinan[2].

Perbedaan agama atau keyakinan pasangan suamiistri dan keduanya tidak saling memahami satu sama lain, tidak ada toleransi di dalamnya, maka yang muncul adalah ketidakharmonisan antara keduanya. Tidak menutup kemungkinan, tindak kekerasan pun akan muncul akibat saling memaksakan keyakinan masingmasing.

Faktor lingkungan juga sangat mempengaruhi terjadinya kekerasan dalam rumah tangga seperti terganggunya interaksi antar anggota keluarga ataupun interaksi yang terlalu berlebihan juga bisa memunculkan tindak penyimpangan seperti kekerasan[3]. Contohnya seorang suami yang jarang pulang dan memiliki masalah di luar, karena jarangnya interaksi maka anggota keluarga yang lain mungkin tidak mengetahuinya dan ketidaktahuan mereka akan masalah itu mengakibatkan munculnya sikap-sikap yang justru memperburuk suasana seperti anak yang rewel dan istri yang banyak meminta, sehingga emosi sang suami memuncak bahkan memicu ia melakukan tindak kekerasan.

Faktor-faktor tersebut dapat memicu terjadinya kekerasan dalam rumah tangga yang selama ini banyak terjadi. Karena terjadi dalam lingkup rumah tangga kekerasan terhadap istri sesungguhnya kompleks, tetapi sulit mendeteksi jumlah kasus maupun tingkat keparahan korban, karena banyak kasus yang tidak dilaporkan. Para korban cenderung menyembunyikan kekerasan yang mereka alami dengan jalan berdiam diri ataupun mencoba menyembunyikannya dengan mengajukan gugatan perceraian untuk langsung mengakhiri penderitaan mereka.

Hal ini jika tidak ditanggulangi dengan baik dan benar akan membawa dampak yang berkepanjangan, selain korban akan terus menderita juga akan membawa dampak pada psikologi anak. Keadaan yang memojokan perempuan karena dipandang sebelah mata di dalam masyarakat terus mendorong perempuan mulai bergerak memperjuangkan haknya. Tetapi bagaikan pisau bermata dua, kemajuan gerakan wanita ini membawa dampak ganda dalam masyarakat.

Di satu sisi gerakan ini dapat menunjukkan peran serta perempuan dalam masyarakat dan melindungi hak-hak perempuan, salah satunya adalah terjaminnya perlindungan hukum bagi perempuan dari kekerasan yang akhirnya oleh Pemerintah dikukuhkan dengan Undang-undang No 23 tahun 2004 tentang Penghapusan Kekerasan dalam Rumah Tangga.

Akan tetapi di sisi lain gerakan perempuan ini membuat perubahan pola pikir dalam masyarakat, hal ini terbukti dengan semakin meningkatnya gugatan perceraian di Pengadilan. Perubahan pemikiran ini seakan-akan membentuk suatu pandangan bahwa perkawinan bukanlah hal yang sakral sehingga tidak perlu diperjuangkan keutuhannya jika telah ditemukan perbedaan.

Perkawinan yang menyebutkan bahwa "perkawinan ialah ikatan lahir batin antara seorang pria dengan seorang wanita sebagai suami istri dengan tujuan membentuk keluarga yang bahagia dan kekal berdasarkan Ketuhanan Yang Maha Esa, dari penjelasan tersebut akan diketahui bahwa harapan perkawinan 
adalah terbentuknya perkawinan bahagia dan kekal selamanya.

Perubahan pemikiran di kalangan perempuan saat ini membuat perceraian menjadi jalan utama yang secara tidak langsung membuat suatu pendapat jika terjadi kekerasan hanya perceraian yang dapat mengakhirinya. Karena memang penggunaan jalan damai masih dirasa kurang efektif dan tidak memutus mata rantai kekerasan yang terjadi dalam masyarakat.

Hal ini terbukti dengan banyaknya kasus yang diselesaikan di luar pengadilan akan tetapi dalam jangka waktu beberapa bulan pelaku melakukan perbuatannya lagi. Kegagalan untuk menyelamatkan rumah tangga di luar pengadilan inilah yang menciptakan realita kehidupan yang memprihatinkan dengan meningkatnya angka perceraian yang terus setiap tahun.

Padahal penyelesaian di luar pengadilan ini tidak sedikit memberikan harapan keadaan akan pulih paska terjadinya kekerasan dalam rumah tangga. Tetapi tidak dapat dipungkiri bahwa penyelesaian di luar pengadilan memang tidak memberikan jaminan yang pasti kepada korban bahwa pelaku tidak akan mengulangi perbuatan KDRT, hal ini yang membuat banyak pihak menyaksikan keberhasilannya.

Posisi perempuan memang sangat labil dalam keadaan seperti ini, jika ia memutuskan untuk berdiam diri maka dapat dipastikan penderitaannya tidak berakhir akan tetapi jika ia memilih untuk menempuh jalan persidangan tentu banyak pertimbangan dan akibat yang perlu dipikirkan. Perempuan sebagai korban kekerasan dalam rumah tangga memang tidak dapat disalahkan jika ia memilih untuk lepas dari penderitaannya karena itu merupakan salah satu bentuk reaksi perlawanan dari kekerasan yang dialaminya.

Seperti halnya proses penyelesaian kasus-kasus Kekerasan Dalam Rumah Tangga yang terjadi di Desa Tumpak Kecamatan Pujut Kabupaten Lombok Tengah, di Desa ini masih sering terjadi kasus kekerasn dalam rumah tangga karena disebabkan oleh faktor yang sama yaitu faktor internal dan faktor ekstrnal. Dalam kasus ini yang banyak menjadi korban yaitu sebagian besar dari kalangan istri.

Untuk itu dalam proses penyelesaianya yaitu melalui jalur mediasi, mediasi yang dimaksud dalam penelitian ini yaitu proses peyelesaian sengketa di luar pengadilan dengan jalan musyaarah untuk mufkat dengan meminta bantuan pihak ketiga (mediator) sebagai penasehat untuk mendamaikan kedua belah pihak yang bersengketa, karena mediasi itu adalah salah satu bagian dari alternatif penyelesaian sengketa di luar pengadilan. Sistimatika penyelesaian seperti ini merupkan budaya yang turun-menurun dari generasi ke generasi. Proses penyelesan seperti ini telah dibuktikan banyak menyelesaikan permasalahan di dalam masyarakat Desa Tumpak sehingga masih digunakan sampai saat ini, disamping tidak memakan biaya yang banyak juga membutuhkan waktu yang singkat.
Begitu pentingnya keberhasilan penyelesaian kasus kekerasan dalam rumah tangga di luar pengadilan yang dapat menyelamatkan kehidupan rumah tangga, membuat peneliti tertarik untuk meneliti dan menyusunnya dalam skripsi dengan judul "Penyelesaian Kasus Kekerasan dalam Rumah Tangga (KDRT) di Luar Pengadilan di Desa Tumpak Kecamatan Pujut Kabupaten Lombok Tengah”.

\section{B. METODE PENELITIAN}

1. Metode yang Digunakan

Metode penelitian kualitatif adalah metode penelitian yang digunakan untuk meneliti pada kondisi objek yang alamiah[4].

Penelitian kualitatif merupakan kegiatan mencatat keadaan yang sebenarnya terjadi di saat penelitian, tidak direkayasa atau dibuat-buat. Berdasarkan pernyataan di atas maka metode penelitian yang digunakan dalam penelitian ini adalah metode kualitatif yang bersifaf diskriptif. Penelitian ini menyusun desain yang secara terus menerus disesuaikan dengan kenyataan di lapangan.

\section{Subjek Penelitian}

Kata lain dari subjek penelitian adalah responden, atau orang yang memberi respon atas suatu perlakuan yang di berikan kepadanya. Di kalangan penelitian kualitatif, istilah subjek penelitian atau responden di sebut dengan istilah informan, yaitu orang yang memberi informasi tentang data yang di inginkan peneliti berkaitan dengan penelitian yang sedang di laksanakan. Untuk menentukan informan, maka di perlukan teknik Purpossive Sampling dan Snowball Sampling. Purpossive Sampling adalah tehnik pengambilan sampel sumber data dengan pertimbangan tertentu. Pertimbangan tertentu ini, misalnya orang tersebut yang di anggap paling tahu tentang apa yang kita harapkan, atau dia sebagai penguasa sehingga akan memudahkan peneliti menjelajahi obyek/situasi sosial yang di teliti[5].

Sedangkan Snowball Sampling adalah teknik penentuan sampel yang mula-mula jumlahnya kecil, kemudian membesar. Ibarat bola salju yang menggelinding yang lama-lama menjadi besar. Dalam penetuan sampel pertama-tama dipilih satu atau dua orang, tetapi karena dengan dua orang ini belum merasa lengkap terhadap data yang diberikan, maka peneliti mencarai orang lain yang dipandang lebih tahu dan dapat melengkapi data yang diberikan oleh dua orang sebelumnya. Begitu seterusnya, sehingga jumlah sampel semakin banyak[6]. Berdasarkan hal terebut di atas dapat disimpulkan bahwa penentuan teknik sampel dalam penelitian ini menggunakan Snowball Sampling. Subyek dalam penelitian ini adalah Tokoh Adat, Tokoh Agama, Kepala Desa Kepal Dusun dan Masyarakat Setempat di Desa Tumpak Kecamatan Pujut Kabupaten Lombok Tengah

3. Jenis Dan Sumber Data 


\section{a. Jenis Data}

Jika dilihat dari wujudnya jenis data pada penelitian dasarnya dapat dikelompokkan menjadi 2 yaitu 1) Data kualitatif yaitu data yang dinyatakan dalam bentuk dokumen pribadi, catatan lapangan, ucapan, dan tindakan responden, dokumen dan lain-lain. 2) Data kuantitatif yaitu data dari hasil pengukuran variabel yang dioperasikan dengan menggunakan instrumen yang dinyatakan dalam bentuk angka-angka[7]. Adapun jenis data yang digunakan dalam penelitian ini yaitu menggunakan data penelitian kualitatif, untuk memperoleh data yang berbentuk kata, data skema dan gambar.

\section{b. Sumber Data}

Untuk mendapatkan data yang valid dan objek terhadap permasalahan yang diteliti maka perlu untuk menjelaskan informasi sekaligus karakteristik serta jenis data yang dikumpulkan sehingga berkualitas, validitas dan keakuratan data yang diperoleh dapat dimengerti. Sumber data yang dimaksud dalam penelitian ini adalah subjek penelitian atau informan atau subjek darimana data diperoleh[8].

Sumber data yang digunakan dalam penelitian ini adalah informasi atau subjek dan benda serta situasi lingkungan secara keseluruhan darimana data-data yang relevan untuk terjawabnya masalah penelitian ini. Sumber data merupakan suatu informasi yang bersumber dari dokumen tertulis, benda-benda, kejadian atau peristiwa, atau biasa juga melalui wawancara dengan subjek yang diteliti[9].

Ada dua macam sumber data dalam penelitian ini yaitu Sumber Data Primer dan Data Skunder[10].

\section{1) Sumber Data Primer}

Sumber data primer adalah sumber data yang diperoleh secara langsung dari informan di lapangan yaitu melalui wawancara mendalam (indept interview) dipergunakan untuk memperoleh data dengan metode wawancara dengan Narasumber yang akan diwawancarai.

\section{2) Sumber Data Sekunder}

Sumber data sekunder adalah sumber data yang diperoleh secara tidak langsung dari informan di lapangan, misalnya lewat orang lain, dokumen, arsiparsip, publikasi, dan artikel mengenai masalah yang diteliti.

Sumber data primer dalam penelitian ini adalah hasil dari wawancara dengan orang yang memberikan data secara langsung dalam hal ini adalah para mediator yang bisa ditunjuk dalam penyelesaian kasus kekerasan dalam rumah tangga (KDRT) di luar pengadilan, misalnya Tokoh Agama, Kepala Dusun, Kepala Desa dan Masyarakat serta Keluarga para pihak yang terkait dengan kasus Kekerasan Dalam Rumah Tangga (KDRT) tersebut. Sedangkan sumber data skunder dalam penelitian ini yaitu data yang diperoleh dari dokumendokumen resmi, buku-buku yang berhubunngan dengan objek penelitian, hasil penelitian dalam bentuk laporan, dokumen, majalah, refrensi dan berbagai buku atau berbagi informasi dari media masa.

\section{Teknik Pengumpulan Data}

Dalam melaksanakan kegiatan penelitian, agar memperoleh data yang akurat diperlukan berbagai teknik atau cara untuk mengumpulkannya. Adapun metode yang digunakan dalam peneltian ini antara lain:

\section{a. Metode Observasi}

Observasi merupakan suatu proses yang kompleks, suatu proses yang tersusun dari berbagai proses biologis dan psikologis[11]. Observasi adalah pengumpulan data yang dilakukan meluali pengamatan langsung dan pencatatan secara sistematis yang digunakan untuk memperoleh informasi. Penetian ini menggunakan teknik observsi, yaitu penulis mengadakan pengamatan langsung terhadap objek yang diteliti dan digunakan sebagai kelengkapan informasi data yang belum diperoleh sebelumny.

Adapun data yang dikumpulkn dari metode observasi ini yaitu:

1) Observasi tentang faktor-faktor pendorong terjadinya kasus kekerasan dalam rumah tangga (KDRT) di Desa Tumpak Kecamatan Pujut Kabupaten Lombok Tengah

2) Observasi terhadap proses penyelesaian kasus kekerasan dalam rumah tangga (KDRT) dalam hukum adat masyarakat Desa Tumpak Kecamatan Pujut Kabupaten Lombok Tengah.

b. Metode Dokumentasi

Dokumentasi adalah mencari dan mengumpulkan data mengenai hal-hal yang berupa catatan, transkip, buku, surat kabar, majalah, notulen, raport, agenda dan sebagainya[12]. Teknik dokumentasi adalah pengumpulan data mengenai hal-hal yang berkaitan dengan penelitian yang berupa catatan, buku, surat, majalah dan lain-lain.

Dokumentasi yang peneliti maksudkan adalah teknik dokumentasi yang digunakan untuk memperoleh data tentang keadaan lokasi atau wilayah Desa Tumpak,, jumlah pelaku KDRT di Desa Tumpak, jumlah dusun dan Kepala Dusun di Desa Tumpak. Kemudian jumlah penduduk yang peneliti maksudkan yaitu jumlah penduduk berdasarkan tingkat pendidikan usia dan jenis kelamin.

\section{c. Metode Wawancara}

Wawancara adalah pertemuan dua orang untuk bertukar informasi dan ide melalui tanya jawab, sehingga dapat dikonstruksikan makna dalam suatu topik tertentu[13]. Wawancara digunakan sebagai teknik pengumpulan data apabila peneliti ingin melakukan studi dalam menemukan masalah yang ingin diteliti. Selain itu wawancara juga dipakai apabila peneliti ingin tau hal-hal yang spesifik dari orang yang dijadikan sampel dalam penelitian. 
Dalam melakukan wawancara harus memiliki pedoman yang biasanya disebut pedoman wawancara. Beberapa macam wawancara yaitu:

1) Pedoman Wawancara Terstruktur adalah wawancara yang daftar pertanyaannya telah ditentukan secara sistematis. Wawancara terstruktur ini digunakan sebagai teknik pengumpulan data, bila peneliti atau pengumpul data telah mengetahui dengan pasti tentang informasi apa yang akan diperoleh.

2) Pedoman wawancara tidak terstruktur adalah wawancara yang bebas dimana peneliti tidak menggunakan pedoman wawancara yang telah tersusun secara sistematis dan lengkap untuk pengumpulan datanya.

3) Pedoman wawancara semiterstruktur merupakan jenis wawancara yang termasuk kategori in-depth interview, dimana dalam pelaksanaanya lebih bebas bila dibandingkan dengan wawancara terstruktur. Tujuan dari wawancara jenis ini adalah untuk menemukan permasalahan secara lebih terbuka, dimana pihak yang diajak wawancara diminta pendapat dan ide-idenya.

Pedoman wawancara yang digunakan dalam penelitian ini adalah pedoman wawancara tidak terstruktur yaitu wawancara yang daftar pertanyaannya tidak ditentukan secara sistematis, maksudnya yaitu peneliti bebas mengajukan pertanyaan kepada pemberi informasi, namun peneliti tetap berpatokan pada format yang disusun sebelumya.

Adapun orang yang akan diwawancara dalam metode ini yaitu para mediator dan para pihak yang terlibat dalam kasus KDRT tersebut sebperti:
a) Kepala Desa
b) Kepala Dusun
c) Tokoh Agama
d) Masyarakat/para pihak yang terlibat serta kelurganya

\section{Tenik Analisis Data}

Analisis Data adalah proses mencari dan menyusun secara sistematis data yang diperoleh dari hasil wawancara, catatan lapangan, dan dokumentasi, dengan cara mengorganisasikan kedalam kategori, menjabarkan ke dalam unit-unit[4]. Teknik analisis yang digunakan dalam penelitan ini adalah teknik analisis data kualitatif dengan menggunakan metode intraktif.

Bila jawaban yang diwawancarai setelah dianalisis ternyata belum memuaskann, maka peneliti akan melanjutkan pertanyaan lagi, sampai tahap tertentu, diperoleh data yang kredibel.

Adapun aktivitas dalam analisis data, yaitu Reduksi Data (Data Reduction), Penyajian Data (Data Display) dan menarik Kesimpulan (Conclusion Draing).

a. Reduksi Data (Data Reduction)
Mendiskripsikan data berarti merangkum, memilih hal-hal yang pokok, memfokuskan pada hal-hal yang penting, dicari tema dan polanya.

b. Penyajian Data (Data Display)

Seteah data direduksi maka langkah selanjutnya adalah menyajikan data. Penyajian data bisa dilakukan dalam bentuk uraian singkat, bagan, hubungan antar kategori dan sejenisnya.

c. Penarikan Kesimpulan (Conclsion Drawing)

Penarikan kesimpulan merupakan temuan baru yang sebelumnya belum pernah ada temuan dapat berupa deskripsi atau gambaran suatu objek yang sebelumya masih remang-remang atau gelap sehingga setelah diteliti menjadi jelas.

\section{HASIL DAN PEMBAHASAN}

1. Faktor-Faktor Pendorong Terjadinya Kasus Kekerasan Dalam Rumah Tangga (KDRT) di Desa Tumpak Kecamatan Pujut Kabupaten Lombok Tengah

Untuk mengetahui faktor-faktor yang mendorong terjadinya tindak pidana kekerasan dalam rumah tangga di desa Tumpak, maka yang pertama harus di lihat adalah gambaran dari hasil penelitian tentang jumlah kekerasan dalam rumah tangga yang di laporkan pada kepolisian Kabupaten Lombok Tengah selama 4 tahun terakhir yaitu tahun 2013-2016.

a. Usia Nikah Terlalu Muda (Nikah Dini)

Usia menikah minimal bagi laki-laki 23 tahun dan bagi perempuan minimal 19 tahun, namun pada kenyataannya yang sering terjadi di Desa Tumpak tidak sesuai dengan apa yang telah ditetentukn. Data yang dihasilkan peneliti terkait kasus KDRT di Desa Tumpak juga didominasi oleh pernikahan dini, di mana baik suami maupun istrinya usianya belum cukup untuk menjalani bahtera rumah tangga, karena emosinya masih labil. Kini di Desa Tumpak pernikahan dini merupakan pemicu munculnya pelanggaran HAM yaitu kekerasan dalam rumah tangga (KDRT).

Hal ini sesuai dengan apa yang diungkapkan oleh Sairi (15 Desember 2016) selaku Ketua Karang Taruna Desa Tumpak mengungkapkan bahwa:

Dengan banyaknya jumlah usia pernikahan di bawah umur (pernikahan dini) maka di Desa Tumpak ini sering skali terjadi kekerasan dalam rumah tangga karena belum memahami apa arti dan tujuan berumah tangga karena yang paling dominan disini adalah masalah biologisnya sehingga terjadi perkawinan sehingga rentan terjadi masalah dalam mengarungi sebuah rumah tangga.

Pendapat Sairi di atas sejalan dengan apa yang diungkapkan oleh Ompul (15 Desember 2016) selaku Tokoh Agama Dusun Bongak menyatakan bahwa:

Di Dusun Bongak ini banyak terjadi yang namanya pernikahan di bawah umur itu, segingga sering terjadi kasus kekerasan dalam rumah tangga karena pemikirannya belum matang belum tau apa arti dan tujuan berumah tangga itu, yang penting mereka menikah belum memikirkan apa yang akan terjadi kedepan nanti. 
Penyebab banyaknya terjadi pernikahan dini di Desa Tumpak adalah salah satunya yaitu, hamil di luar nikah, dengan pernikahan yang dipaksakan ini baik pria dan wanita tersebut belum siap menjalani rumah tangga sehingga sulit untuk menyatukan persepsi keduanya, apalagi tidak ditopang dengan ekonomi yang mapan.

Dengan usia nikahnya yang rata-rata masih dibawah umur, maka pemikiran dan emosionalnya belum bias dikatakan sudah matang sehingga belum mengerti apa makna dan tujuan dibentuknya rumah tangga, karena yang paling dominan disini adalah masalah biologisnya. Pernikahan itu sangat menentukan kehidupan rumah tangga seseorang.

Usia menikah minimal bagi laki-laki 23 tahun dan bagi perempuan minimal 19 tahun, namun pada kenyataannya yang sering terjadi di Desa Tumpak tidak sesuai dengan apa yang telah ditetentukn. Data yang dihasilkan peneliti terkait kasus KDRT di Desa Tumpak juga didominasi oleh pernikahan dini, di mana baik suami maupun istrinya usianya belum cukup untuk menjalani bahtera rumah tangga, karena emosinya masih labil.

Kini di Desa Tumpak pernikahan dini merupakan pemicu munculnya pelanggaran HAM yaitu kekerasan dalam rumah tangga (KDRT). Jadi yang menyebab banyaknya terjadi pernikahan dini di Desa Tumpak adalah salah satunya yaitu, hamil di luar nikah, dengan pernikahan yang dipaksakan ini baik pria dan wanita tersebut belum siap menjalani rumah tangga sehingga sulit untuk menyatukan persepsi keduanya, apalagi tidak ditopang dengan ekonomi yang mapan.

Dengan usia nikahnya yang rata-rata masih dibawah umur, maka pemikiran dan emosionalnya belum bias dikatakan sudah matang sehingga belum mengerti apa makna dan tujuan dibentuknya rumah tangga, karena yang paling dominan disini adalah masalah biologisnya. Jadi usia pernikahan itu sangat menentukan kehidupan rumah tangga seseorang.

\section{b. Hadirnya Orang Ketiga (Perselingkuhan)}

Dalam kehidupan berumah tangga perselingkuhan merupakan salah satu penyebab ambruknya rumah tangga seseorang. Begitu juga yang trjadi di Desa Tumpak, telah banyak trjadi kasus KDRT disebabkan karena perselingkuhan. Perselingkuhan merupakan salah satu permasalahan yang kerap kali menjadi penyebab retaknya rumah tangga seseorang. Meski tidak selalu berakhir dengan perceraian, perselingkuhan dapat dipastikan tetap akan merugikan pihak-pihak yang dikecewakan. Entah berkurangnya kepercayaan, penyebab rasa cinta berkurang dan sebagainya yang akan mengurangi keharmonisan rumah tangga itu sendiri.

Hal ini sesuai dengan apa yang diungkapkan oleh Sairi dalam wawancara (15 Desember 2016) di Dusun Bongak menyatakan bahwa:

Kehadiran orang ketiga atau perselingkuhan merupakan suatu yang sangat tidak diinginkan karena perselingkuhan itu apabila diketahui baik itu dari kalangan suami maupun istri maka ujung-ujungnya akan terjadi kekerasan dalam rumah tangga sehingga salah satu diantara suami maupun istri tidak akan mau menerima bahwa pasanganya selingkuh.
Ungkapan Sairi diatas senada dengan apa yang diungkapkan oleh Ompul (15 Desember 2016) dalam wawancara di Dusun Bongak menyatakan bahwa:

Kalau sudah terjadi yang namanya selingkuh itu, apabila diketahui baik itu permpuan maupun laki-laki pasti hancur seketika rumahtangganya, apalagi kita sebagai laki-laki mengetahui istri kita selingkuh tidak ada ampun maaf bagi mreka pingin kita pukuli langsung, kadang-kadang sebagian besar masyarakat Desa Tumpak bercerai karena masalah itu.

Dalam hal ini berselingkuh bisa menjadi pilihannya.elima yaitu, Masalahan Seksual, selain memang menjadi kebutuhan manusia, dalam kehidupan rumah tangga, kepuasan dalam hubungan seksual juga menjadi salah satu kunci keharmonisan rumah tangga seseorang. Sehingga jika dalam faktor seksual terjadi permasalahan, baik akibat hilangnya keperawanan, terjadinya kejenuhan, maupun adanya kelainan seksual, maka ketika hal ini tidak segera diselesaikan bisa jadi akan menimbulkan niat melakukan perselingkuhan.

Hadirnya mantan, Meski sudah berstatus menikah, tidak menutup kemungkinan bagi seseorang untuk merasa jatuh cinta kembali kepada mantan pacarnya atau orang yang dahulu pernah ia cintai. Terlebih jika orang yang ia suka kembali muncul ketika ia sedang mengalami permasalahan dengan pasangannya. Pada saat-saat seperti ini biasanya ia akan kembali mengingat dan merindukan kenangan-kenangan lama serta membandingkan dengan kekurangan pasangannya, sehingga muncul keinginan untuk sekedar bertemu yang dapat berlanjut menjalin hubungan khusus.

Dalam kehidupan berumah tangga perselingkuhan merupakan salah satu penyebab ambruknya rumah tangga seseorang. Begitu juga yang trjadi di Desa Tumpak, telah banyak trjadi kasus KDRT disebabkan karena perselingkuhan. Perselingkuhan merupakan salah satu permasalahan yang kerap kali menjadi penyebab retaknya rumah tangga seseorang. Meski tidak selalu berakhir dengan perceraian, perselingkuhan dapat dipastikan tetap akan merugikan pihak-pihak yang dikecewakan. Entah berkurangnya kepercayaan, penyebab rasa cinta berkurang, dan sebagainya yang akan mengurangi keharmonisan rumah tangga.

\section{c. Masalah Ekonomi}

Faktor ekonomi adalah salah satu pemicu terjadinya kekerasan dalam rumah tangga di Desa Tumpak, alasannya dikarenakan kebutuhan hidup yang semakin tinggi tidak sesuai dengan pendapatan atau kebutuhan yang di raih. Sehingga dengan keadaan yang seperti itu dapat menimbulkan berbagai perselisihan dalam rumah tangga dalam kehidupan sehari-hari, karena tuntutan dari pasangan atau dari anaknya tidak terpenuhi. Karena ekonomi merupakan hal yang paling diutamakan dalam menjalin hubungan berumah tangga, dengan ekonomi seseorang bias hidup bahagia dan sejahtra.

Menurut pendapat Sairi dalam wawancara (15 Desember 2016) di Dusun Bongak menyatakan bahwa:

Banyak masyarakat Desa Tumpak yang melakukan tindak kekerasan dalam rumah tangga yang karena dilatar belakangi oleh rendahnya ekonomi dalam kehidupan rumah tangganya, kadang tidak merasa terpenuhi keinginannya sehingga lewat itulah timbulnya tindakan kekerasan terhadap istri dan anaknya, karena 
ekonomi sangat menentu kehidupan seseorang, seperti yang sering terjadi di Dusun Bongak ini banyak masyarakat yang rumah tangganya kurang harmonis lantaran masalah ekonominya yang masih minim bahkan itu menjadi suatu permasalahan yang serius dalam rumah tangganya.

Ungkapan sairi diatas sejalan dengan apa yang diungkapkan oleh Supardi dalam wawancara (16 Desember 2016) di Mekar Indah.

Sebagian besar masyarakat desa tumpak ekonominya masih di bawah standar sehingga banyak masyarakat mengaku dirinya kurang mampu, baik dari biaya pendidikan anaknya, biaya kesehatan dan juga biaya hidup sehari-hari, sehingga dengan keadaaan seperti ini membuat seringnya terjadi kasus kekerasan dalam rumah tangganya, dan juga jangan heran dengan adanya kejadian seperti ini karena wajar lah yang namanya orang bosen ndak ada untuk belanja dan sebagainya.

Ekonomi sering menjadi masalah dalam keluarga karena tidak merasa puas, akibatnya yaitu sering membuat seseorang melakukan tindak kekerasan dalam rumah tangga. Sebagian besar masyarakat Desa Tumpak mengungkapkan bahwa dengan ekonominya yang paspasan maka sering menjadi masalah dalam hidupnya. Ini semua tidak lepas dari kurangnya kesadaran masyarakat dalam membentuk rumah tangga. Untuk itu dalam membangun subuah rumah tangga haruslah didasari dengan kesiapan yang matang, baik itu kesiapan dari segi ekonomi maupun kesiapan mental untuk menempuh kehidupan dalam berumah tangga, supaya tidak terjadi kekerasan dalam rumah tangga.

Faktor ekonomi adalah salah satu pemicu terjadinya kekerasan dalam rumah tangga di Desa Tumpak, alasannya dikarenakan kebutuhan hidup yang semakin tinggi tidak sesuai dengan pendapatan atau kebutuhan yang di raih. Sehingga dengan keadaan yang seperti itu dapat menimbulkan berbagai perselisihan dalam rumah tangga dalam kehidupan sehari-hari, karena tuntutan dari pasangan atau dari anaknya tidak terpenuhi. Karena ekonomi merupakan hal yang paling diutamakan dalam menjalin hubungan berumah tangga, dengan ekonomi seseorang bias hidup bahagia dan sejahtra.

Ekonomi sering menjadi masalah dalam keluarga karena tidak merasa puas, akibatnya yaitu sering membuat seseorang melakukan tindak kekerasan dalam rumah tangga. Sebagian besar masyarakat Desa Tumpak mengungkapkan bahwa dengan ekonominya yang paspasan maka sering menjadi masalah dalam hidupnya. Ini semua tidak lepas dari kurangnya kesadaran masyarakat dalam membentuk rumah tangga.

\section{d. Ikut Campur Orang Tua dan Keluarga Suami} Atau Istri

Orang tua dari pihak suami atau istri dapat menjadi pemicu timbulnya kekerasan dalam rumah tangga. Kekerasan dalam rumah tangga biasanya terjadi karena orang tua dari salah satu pihak selalu ikut campur dalam msalah rumah tangga sehingga pihak lain merasa terganggu. Namun kadang-kadang sebagai orang tua tidak bisa menyadari bahwa apa yang dia lakukaan itu adalah salah, sehingga kadang-kadang anak atau menantunya melampiaskan emosinya kepada istrinya.
Maka hal seperti inilah yang dapat menimbulkan kasus kekerasan dalam rumah tangga di Desa Tumpak. Orang tua juga mempunyai hak untuk ikut campur terhadap keluarga atau anak-anaknya namun tidak sepenuhnya untuk menuangkan hak-haknya kepada rumah tangga anaknya. Sebagai orang tua haruslah mengerti akibat dari ikut campurnya terhadap anaknya, karena telah banyak kasus yang rumah tangganya hancur yang disebabkan oleh orang tua.

Seorang informan Inaq Pian 33 tahun dalam wawancara Dusun Lendang Lantan (18 Desember 2016) menyatakan dengan singkat:

Kadang juga yang membuatku dan suamiku sering bertengkar disebabkan karena mertuaku yang selalu ikut campur dalam urusan rumah tanggaku, seperti-kejadian-kejadian yang sudah lewat kalau ada cara saya sdikit saja yang dia tidak sukai trus mertuaku langsung ikut campur dalam masalah kluargaku, bagaima bagaimana saya tidak melawan padahal kadang-kadang saya berada pada posisi yang benar tapi masih aja saya dimarahin sehingga itu yang membuat saya melawan mereka, ahirnya suami itu yang membuat suami saya marahin sama saya karena saya melawan mertuaku akhirnya itu tang membuat suamiku pukuli aku.

Ungkapan Inaq Pian diatas sejalan dengan apa yang diungkapkan oleh Ajap dalam wawancara (17 Desember 2016) di Dusun Bun Lesung menyatakan bahwa:

Memang benar kalau mertuaku suka ikut campur bias membuatku sering berantam sama istriku, kadang kala dia tidak tau alur permasalahanku itu tapi yang penting mertuaku ikut-ikutan sehingga itu yang membuatku marah dan memukuli istriku.

Dengan demikian faktor pendorong terjadinya kasus kekerasan dalam rumah tangga dapat disebabkan oleh adanya faktor tersebut. Artinya dapat dipengaruhi oleh faktor dari luar atau lingkungan, tetapi dapat juga dipicu karena adanya faktor dari dalam dari perilaku sendiri. Hal ini dapat diperoleh dari kasus-kasus yang pernah terjadi di Desa Tumpak dan ditangani oleh para tokoh dalam masyarakat.

Orang tua dari pihak suami atau istri dapat menjadi pemicu timbulnya kekerasan dalam rumah tangga. Kekerasan dalam rumah tangga biasanya terjadi karena orang tua dari salah satu pihak selalu ikut campur dalam msalah rumah tangga sehingga pihak lain merasa terganggu. Namun kadang-kadang sebagai orang tua tidak bisa menyadari bahwa apa yang dia lakukaan itu adalah salah, sehingga kadang-kadang anak atau menantunya melampiaskan emosinya kepada istrinya. Maka hal seperti inilah yang dapat menimbulkan kasus kekerasan dalam rumah tangga di Desa Tumpak. Orang tua juga mempunyai hak untuk ikut campur terhadap keluarga atau anak-anaknya namun tidak sepenuhnya untuk menuangkan hak-haknya kepada rumah tangga anaknya. Sebagai orang tua haruslah mengerti akibat dari ikut campurnya terhadap anaknya, karena telah banyak kasus yang rumah tangganya hancur yang disebabkan oleh orang tua.

Dalam Undang-Undang No. 23 tahun 2004 tentang penghapusan kekerasan dalam rumah tangga, jenis kekerasan yang dikategorikan sebagai kekerasan dalam rumah tangga, yaitu[14]:

1. Kekerasan Fisik 
Kekerasan fisik adalah perbuatan yang mengakibatkan rasa sakit, jatuh sakit atau luka berat (Pasal 6). Prilaku kekerasan yang termasuk dalam golongan ini antara lain adalah menampar, memukul, meludahi, menarik rambut (menjambak), menendang, memukul/melukai dengan senjata, dan sebagainya. Biasanya perlakuan ini akan nampak seperti bilur-bilur, muka lebam, gigi patah atau bekas luka lainnya.

\section{Kekerasan Psikis}

Kekerasan psikis adalah perbuatan yang mengakibatkan ketakutan, hilangnya rasa percaya diri, hilangnya kemampuan untuk bertindak, rasa tidak berdaya, dan/atau penderitaan psikis berat pada seseorang (Pasal 7). Perilaku kekerasan yang termasuk penganiayaan secara emosional adalah penghinaan, komentar-komentar yang menyakitkan atau merendahkan harga diri, mengisolir istri dari dunia luar, mengancam atau ,menakut-nakuti sebagai sarana memaksakan kehendak.

\section{Kekerasan Seksual}

Kekerasan seksual yaitu pemaksaan yang dilakan terhadap orang yang menetap dalam lingkup ruma tanga trsebut. Selain itu juga berarti pemaksaan hubungan seksual terhadap salah seorang dalam lingkup rumah tangganya dengan orang lain untuk tujuan komersial atau tujuan tertentu (Pasal 8)

\section{Penelantaran Rumah Tangga}

Penelantaran rumah tangga juga dimasukan dalam pengertian kekerasan, karena setiap orang dilarang menelantarkan orang dalam lingkup rumah tangga, padahal menurut hukum yang berlaku baginya atau karena persetujuan atau perjajnian ia wajib memberikan penghidupan, perawatan atau pemeliharaan kepada orang tersebut. Penelantaran tersebut juga berlaku bagi setiap orang yang mengakibatan ketergantungan ekonomi dengan cara membatasi/melarang untuk bekerja yang layak di dalam atau di luar rumah, sehingga korban dibawah kendali orang tersebut (Pasal 9)

\section{Proses Penyelesaian Kasus Kekerasan Dalam Rumah Tangga (KDRT) di Desa Tumpak Kecamatan Pujut Kabupaten Lombok Tengah}

Adapun cara yang dapat dilakukan dalam penyelesaian kasus kekerasan dalam rumah tangga (KDRT) baik itu di pengadilan atau di luar pengadilan antara lain yaitu:

a. Penyelesaian Kasus Kekerasan Dalam Rumah Tangga Melalui Pengadilan Agama

Kebanyakan kasus-kasus Kekerasan Dalam Rumah Tangga (KDRT) yang ditangani oleh Pengadilan Agama tersembunyi dalam perkara-perkara cerai gugat yang diajukan pihak istri. Alasan istri meminta cerai pada umumnya adalah penelantaran ekonomi oleh sang suami, suatu tindakan yang menurut hukum merupakan salah satu bentuk kekerasan dalam rumah tangga. Pada umumnya, perempuan korban KDRT yang datang ke Pengadilan Agama guna menyelesaikan kemelut rumah tangga merupakan pilihan akhir setelah menempuh berbagai penyelesaian. Hal ini tampak pada hampir semua kasus di pengadilan Agama yang selalu menyebutkan telah dilakukannya upaya perdamaian edua belah pihak, namun mengalami kegagalan. Sama ketika hendak melangkah e jenjang perkawinan yang penuh konsekuensi jika tidak boleh dikatakan sebagai resiko, maka jalan perceraian pun mempunyai konsekuensi yang tidak kalah berat yang harus ditempuh. Para hakim mempunyai kewenangan untuk mengusahakan penyelesaian kekeluargaan sebelum memutuskan tali perkawinan.

Selama ini pemahaman tentang KDRT dan cara penyelesaiannya menempuh sistem peradilan pidana (SPP) mulai tingkat kepolisian hingga Peradilan Umum (PN). Padahal penyelesaian kasus-kasus KDRT dapat ditempuh melalui sistem peradilan Agama (SPA), sejak proses mediasi hingga putusan. Berbagai peraturan perundang-undangan yang berlaku secara nasional juga memberikan peluang bagi masyarakat pencari keadilan untuk mengadu, melaporkan dan menyelesaikan masalah rumah tangganya di Pengadilan Agama.

b. Penyelesaian Kasus Kekerasan Dalam Rumah Tangga (KDRT) di Luar Pengadilan di Desa Tumpak.

Paparan data yang peneliti dapat kumpulkan dalam melakukan penelitian mengenai "Proses Penyelesaian Kasus Kekerasan Dalam Rumah Tangga (KDRT) di Luar Pengadilan di Desa Tumpak". terdiri dari 3 tahapan, yaitu tahap Sebelum Penyelesaian, Tahap Pelaksanaan Penyelesaian dan Tahap Akhir Penyelesaian.

Hal ini sesuai dengan apa yang diungkapkan oleh Sairi (15 Desember 2016) selaku Ketua Karang Taruna Desa Tumpak mengatakan bahwa:

Setiap kali ada kasus rumah tangga yang terjadi di Desa Tumpak, maka para pihak yang bersengketa terlebih dahulu menyelesaikan sengketa mereka tanpa melibatkan pihak lain, dalam artian bahwa mereka mencoba melakukan perdamaian tanpa bantuan siapapun, kemudian jika cara ini tidak bisa menghasilkan perdamaian/ kesepakatan, maka barulah mereka meminta orang lain sebagai penengah guna menyelesaiakan sengketa mereka yang sedang mereka hadapi.

Ungkapan Sairi diatas sejalan dengan apa yang diungkapkan oleh seorang informan Ompul 24 tahun (15 Desember 2016) selaku Tokoh Agama di Dusun Bongak mengatakan bahwa:

Kalau di Dusun Bongak ketika mereka sedang ada masalah keluarga, mereka tidak langsung memberitahukan ke Kepala Dusun atau Kepala Desa secara sendirian, namun mereka memanggil, memberitahukan keluarganya terlebih dahulu baru mereka bersama-sama pergi ke Kepala Dusun atau Kepala Desa sebagai Penengah, karena mereka yang bisa didengarkan perkataanya oleh masyarakat.

Seorang informan Amaq Ari 31 tahun pelaku KDRT mengatakan dalam wawancara di Dusun Lendang Lantan (17 Desember 2016).

Saya merasa malu jika langsung ke kepala desa karena masalah keluarga saya adalah masalah pribadiku, lebih baik saya panggil ibu bapak saya duluan supaya mereka tahu masalah saya baru kami sama-sama pergi ke kepala desa.

Hal ini juga senada dengan apa yang diungkapkan oleh H. Lalu Najamudin dalam wawancara di Dusun Lendang Lantan (19 Desember 2016) selaku Sekdes Tumpak mengatakan bahwa:

Setiap masyarakat yang datang melaporkan permasalahnya kepada saya, maka saya sebagai orang yang diprcaya oleh para pihak menanyakan mereka secara baik-baik apa yang menjadi masalahnya, kemudian siapa saja yang 
terlibat. Setelah semuanya jelas maka barulah saya memberitahukan kepada mereka kapan waktunya untuk melakukan penyelesaian permasalahan (mediasi) dan mereka harus hadir pada waktu yang sudah ditentukan. Setelah kita bersama-sama duduk bertemu pada waktu yang sudah ditentukan tersebut maka barulah proses penyelesaian masalah (mediasi) mulai dilakukan.

Tahap yang ketiga yaitu tahap akhir penyelesaian sengketa (tahap akhir mediasi), tahap akhir penyelesaian ini merupakan proses akhir dari rangkaian penyelesaian sengketa (mediasi) yang dilakukan, jika para pihak yang bersengketa berhasil mencapai kesepakatan dalam pertemuan penyelesaian sengketa tersebut, maka para pihak hanyalah menjalankan hasil-hasil kesepakatan perdamaian yang telah mereka tungkan dalam bentuk perjanjian tanpa ada yang dipermasalahkan lagi yang disimbolkan dengan cara berjabat tangan.

Jadi proses penyelesaian kasus kekerasa dalam rumah tangga (KDRT) dapat dilakukan tiga cara yaitu:

1) Pihak Yang Bersengketa Menyelesaikan Kasusnya Sendiri Tanpa Bantuan Pihak Ketiga Sebagai Penengah (Mediator).

Menurut analisis penulis bahwa cara ini bukanlah termasuk kategori mediasi Akan tetapi, cara ini disebut negosiasi dimana negosiasi itu adalah komunikasi dua arah yang dirancang untuk mencapai kesepakatan pada saat kedua belah pihak memiliki berbagai kepentingan yang sama maupun yang berbeda. Proses ini tidak melibatkan pihak ketiga karena para pihak berinisiatif sendiri menyelesaikan sengketa mereka. Sedangkan pada prinsipnya dalam proses penyelesaian sengketa (mediasi) harus ada pihak ketiga yang bertindak sebagai Penengah (mediator). Dalam Peraturan Mahkamah Agung No 1 tahun 2008 pasal 8 ayat (1) mengatakan bahwa:

Para pihak berhak memilih mediator dari hakim bukan pemeriksa perkara dari pengadilan yang bersangkutan ataupun dari advokat atau akadmisi hokum.

Berdasarkan ketentuan pasal 8 ayat (1) diatas bahwa para pihak yang melakukan penyelesaian sengketa (mediasi) harus menunjuk seorang mediator sebagai penengah, namun praktek penyelesaian sengketa (mediasi) yang dilakukan masyarakat Desa Tumpak tidak sesuai dengan peraturan perundang-undangan yang ada maka cara pertama ini bukanlah termasuk mediasi.

2) Pihak Yang Bersengketa Meminta Bantuan Kepada Keluarganya Untuk diselesaikan (Dimediasi)

Para pihak tersebut meminta keluarganya sebagai penengah (mediator) untuk mengantisifasi supaya rahasia-rahasia keluarga tersebut tidak tersebar luas ke ranah publik. Sehingga cukup diketahui oleh intern keluarga saja dan bisa dijaga rahasia tersebut. Menurut analisa penulis bahwa cara tersebut masuk dalam kategori mediasi, karena cara tersebut sejalan dengan prinsip mediasi yaitu kerahasiaan (confidiality) artinya bahwa segala sesuatu yang terjadi dalam proses mediasi tidak boleh disiarkan kepada publik. Disamping itu juga cara tersebut sejalan dengan apa yang diajarkan oleh AlQur'an untuk menyelesaikan sengketa dengan jalan tahkim (mediasi) sebagaimana yang dijelskan dalam surat An-Nisa ayat 35, yang artinya:
Ada persengketaan antara keduanya maka kirimlah seorang hakam dari keluarga laki-laki dan seorang hakam dari keluarga perempuan

Ayat tersebut menjelaskan bahwa ketika ada sengketa keluarga maka hendaklah meminta kelurga sebagai hakam (mediator). Supaya para pihak bisa lebih transparan dalam mengungkapkan masalahnya.

3) Pihak Yang Bersengketa Dengan Sukarela SamaSama Sepakat Untuk Datang Meminta Kepala Dusun Atau Kepla Desa Sebagai Penengah (Mediator)

Menurut penulis bahwa cara ini juga adalah termasuk mediasi karena cara tersebut sudah sesuai dengan prinsip-prinsip mediasi yang ada yaitu prinsip sukarela (volunteer). Artinya bahwa masing-masing pihak yang berkasus melakukan mediasi atas keinginan sendiri, secara sukarela dan tidak ada paksaan atau tekanan dari pihak lain.

Secara garis besar Proses Penyelesaian Kasus Kekerasan Dalam Rumah Tangga dalam hukum adat dapat dikemukakan sebagai berikut[15]:

Para pihak yang bersengketa dapat meminta bantuan kepada pihak ketiga (mediator) untuk menyelesaikan sengketa mereka. Mediator yang dipercayakan oleh para pihak, umumnya adalah Tokoh Adat atau Tokoh Masyarakat maupun Tokoh Agama. Selanjutnya yaitu para pihak yang memberikan kepercayaan kepada Tokoh Adat sebagai orang ketiga (mediator) didasarkan kepada kepercayaan bahwa mereka adalah orang yang memiliki wibawa, dihormati, disegani, dipatuhi perkataanya dan mereka adalah orang-orang yang bisa menjaga rahasia di balik persengketaan yang terjadi di antara para pihak. Tokoh adat yang mendapat kepercayaan sebagai orang ketiga (mediator) melakukan pendekatan-pendekatan yang menggunakan bahasa adat dan bahasa agama, agar para pihak yang bersengketa dapat duduk bersama, menceritakan latar belakang, penyebab sengketa dan kemungkinan-kemungkinan mencari jalan keluar untuk mengakhiri sengketa.

Proses penyelesaian sengketa dengan cara ini sudah dikenal jauh sebelum kemerdekaan, dimana seseorang yang terlibat dalam persengketaan, cara penyelesaian sengketanya dilakukan dengan cara damai dan melibatkan pihak ketiga. Pihak ketiga tersebut biasanya adalah Tokoh Masyarakat, Tokoh Agama atau Pimpinan Adat. Penggunaan penyelesaian dengan jalur mediasi atau dengan cara musyawarah, mufakat ini adalah salah satu cara penyelesaian sengketa yang banyak dipilih oleh masyarakat, karena proses berperkara di pengadilan yang lama dan membutuhkan biaya yang mahal.

\section{SIMPULAN DAN SARAN}

Hasil penelitian ini menunjukkan bahwa 1) proses penyelesaian kasus kekerasan dalam rumah tangga (KDRT) yang dilakukan oleh masyarakat desa tumpak ada tiga cara yaitu para pihak menyelesaikan kasusnya tanpa bantuan penengah (mediator). Hal ini bukan termasuk dalam kategori mediasi karena mediasi itu harus ada pihak ketiga sebagai penengah (mediator), para pihak yang bersengketa meminta keluarganya sebagai penengah (mediator) dalam sengketa mereka untuk menjamin terjaganya kerahasiaan dalam pertemuan penyelesaian sengketa (mediasi). Hal ini 
sudah tepat, karena sudah sesuai dengan prinsip-prinsip penyelessaian sengketa di luar pengadilan dengan bermusyawarah dan menjaga kerahasiaan. Para pihak yang bersengketa meminta kepala dusun/ kepala desa sebagai penengah (mediator) kemudian melakukan penyelesaian sengketa secara bermusyawarah. 2) Faktorfaktor yang mendoorong terjadinya kasus KDRT yaitu usia nikah terlalu muda (nikah dini), hadirnya orang ketiga (perselingkuhan), ekonomi yang rendah dan ikut campur orang tua dan keluarga suami atau istri.

\section{UCAPAN TERIMA KASIH}

Penulis mengucapkan terima kasih kepada editor yang senantiasa memberikan saran dan masukan kepada penulis sehingga artikel ilimiah ini selesai dengan baik.

\section{DAFTAR RUJUKAN}

[1] U.-U. R. I. Nomor, “Tahun 2004 tentang Penghapusan Kekerasan Dalam Rumah Tangga,” Lembaran Negara Republik Indones. Nomor, vol. 95, 23AD.

[2] H. Abdurrachman, "Perlindungan Hukum Terhadap Korban Kekerasan Dalam Rumah Tangga dalam Putusan Pengadilan Negeri Sebagai Implementasi Hak-Hak Korban,” J. Huk. Ius Quia Iustum, vol. 17, no. 3, pp. 475-491, 2010.

[3] R. D. Anggraeni, "Dampak Kekerasan Anak dalam Rumah Tangga," 2013.

[4] P. D. Sugiyono, "Metode Penelitian dan Pengembangan," Res. Dev. D, 2015.

[5] L. J. Moleong, Metodologi penelitian. 1999.

[6] Sugiyono, "Metode penelitian kombinasi (mixed methods)," Bandung Alf., 2015.

[7] A. Sugiyono, "Pengantar Statistik Pendidikan," Jakarta Graf. Persada, 2004.

[8] M. Huda, "Model-Model Pengajaran Dan Pembelajaran," Yogyakarta: Pustaka Pelajar, 2014.

[9] N. Sudjana, Belajar dan Faktor-faktor yang Mempengaruhinya. 2010.

[10] P. Sugiyono, "Dr. 2010," Metod. Penelit. Kuantitatif, Kualitatif, dan R\&D. Bandung CV Alf.

[11] S. Hadi, "Metodologi research jilid I," Yogyakarta Andi, vol. 94, p. 95, 2004.

[12] A. Suharsimi, "Prosedur penelitian suatu pendekatan praktik," Jakarta: Rineka Cipta, 2006.

[13] K. G. Esterberg, "Qualitative methods in social research," 2002.

[14] M. H. Soeroso, Kekerasan dalam rumah tangga dalam perspektif yuridis-viktimologis. Sinar Grafika, 2010.

[15] D. Y. Witanto, Hukum keluarga: hak dan kedudukan anak luar kawin: pasca keluarnya putusan $M K$ tentang uji materiil UU perkawinan. Prestasi Pustaka, 2012. 